\title{
Effectiveness of the Implementation of Cognitive Conflict Strategy Assisted by e-Service Learning to Reduce Students' Mathematical Misconceptions
}

\author{
https://doi.org/10.3991/ijet.v15i11.11802 \\ Ni Nyoman Parwati $\left.{ }^{(}\right)$, I Gusti Putu Suharta \\ Universitas Pendidikan Ganesha, Singaraja, Indonesia \\ nyoman.parwatieundiksha.ac.id
}

\begin{abstract}
Students' mathematical misconceptions are types of errors that are carried out consistently in different contexts as a result of errors in the cognitive structure of students. The purpose of this study is to describe the types of errors made by students in solving mathematical problems and to determine the effectiveness of the application of assisted by e-Service Learning, in reducing misconceptions and improving students' mathematical problem-solving abilities. The population of this study was seventh-grade junior high school students in Buleleng Regency. The sample of this study consisted of 109 students spread across three school areas, determined by the area cluster random sampling technique. Research data were collected using tests, observation sheets and interview guidelines. Data analysis was performed descriptively qualitatively and using the t-test. The results of this study were the number of students who experienced substantial errors of $29.4 \%$ consisting of $22.2 \%$ misunderstanding the concept and $7.2 \%$ misconceptions; and technical errors $41.7 \%$ consisting of $13.6 \%$ arithmetic errors, $14.5 \%$ procedural errors, and $13.6 \%$ symbol errors. The application of Cognitive Conflict Strategies assisted by e-Service Learning can reduce student' misconceptions by $85 \%$ and is effective in improving students' mathematical problem-solving abilities.
\end{abstract}

Keywords-Cognitive conflict strategies, e-service learning, mathematics problem-solving ability, misconceptions, types of errors

\section{Introduction}

Problem-solving is a core activity in learning mathematics. The ability of students in solving mathematical problems is still low. The low ability of students' mathematical problem-solving will have a direct impact on their low mathematics learning outcomes [1-2-3]. Student mistakes in general mathematical problem solving can be in the form of procedural errors and concept errors [4-5]. Misconceptions or misconceptions in mathematics are interpreted as consistent concept errors in solving different problems. The occurrence of misconceptions can be caused by many factors, including prior experience. Previous experience will color the 
formation of student schemata and these schemata can be developed into schemas or expected concept knowledge.

The misconception is closely related to the ability of representation. Students who experience misconceptions will be very disturbed in the representation of mathematical ideas. In fact, the ability of representation is one of the standard processes recommended by the National Council of Teachers of Mathematics (NCTM), which must receive serious attention by mathematics teachers. Mathematical representation is the basis for a person to understand and use their ideas. Mathematical representations are used to organize record and communicate mathematical ideas. The importance of representation is reinforced by [6-7-8] that fluency in constructing concepts is very useful in learning mathematics, and can be used in problem-solving.

Therefore, the assessment and handling of students' misconceptions through research is important. One strategy that can be used to reduce misconceptions is cognitive conflict or conceptual change strategies. The effectiveness of Cognitive Conflict Strategies is still being debated. On one hand, it is found that Cognitive Conflict Strategies are effective against concept change, and on the other hand there are weaknesses in the application of Cognitive Conflict Strategies [9]. The results of the study [10] are students experiencing cognitive conflict, due to a contradiction with the concept that is owned and cannot connect or organize the concept into new concepts.

The conceptual change program can provide a way for teachers to overcome student difficulties, by involving them in challenging mathematical tasks without reducing cognitive burdens [11]. The results of the study [12] are that there is a direct influence of Cognitive Conflict Strategies on contextual learning models on problem-solving abilities.

An alternative way to reduce misconceptions and to be more effective in solving mathematical problems is to implement Cognitive Conflict Strategies aided by eservice learning. According to [9] the context related to the learning environment is helpful in the application of Cognitive Conflict Strategies. The use of e-service learning provides opportunities for students to learn without being limited by space and time; as long as there is an internet connection, they can learn. Students will be trained to solve everyday problems according to the real community environment and are trained in communication and social skills. Based on the foregoing, the problem to be solved in this study is to reduce students' misconceptions through the application of Cognitive Conflict Strategies assisted by e-service learning to improve students' mathematical problem-solving abilities.

\section{$2 \quad$ Literature Review}

\subsection{Errors in mathematics work}

Working on mathematics can be interpreted as solving mathematical problems. Students can use a variety of problem-solving strategies to solve mathematical problems well, such as drawing strategies, countdown, formulas and diagrams. 
Although they can use a variety of strategies, students often experience obstacles in mathematics. The obstacles experienced by these students can be known by the mistakes made by students while working on mathematics. These obstacles may be realized or not realized by students.

Mistakes made by students in mathematics work can occur due to students' difficulties in learning. A child who has difficulty in learning will show the characteristics of the problems experienced, as written by [5], including (a) show lower learning outcomes (below the average value) achieved by the group; (b) the results achieved are not balanced with the work done; (c) slow in carrying out their learning tasks; (d) show inappropriate attitudes; (e) show different behavior and; (f) show emotional symptoms that are not reasonable.

In general, the mistakes made by students in working on mathematical problems can be grouped into two, namely technical errors and substantial errors [13]. Technical errors include mistakes made related to calculation errors and the use of imperfect algorithms. Technical errors made by students when working on mathematics problems can be overcome by re-checking the results of problem-solving obtained. For example, when students work on problems $47.1-0.65=$ students find a less precise solution-46.55. Then ask students to check the results obtained by asking whether $0.65+46.55=47.1$. Concept errors, handled by providing remedial teaching or carrying out learning with appropriate learning models. Learning models that can be selected, for example, guided discovery learning models or discovery learning or other learning models that are relevant for concept inculcation. Moreover, it can be helped by using effective learning media according to the level of students' cognitive development [1-6].

Substantial errors include not understanding the concept, and misconceptions. Not understanding the concept, for example, could be expressed via lack of knowledge about symbols, incorrect use of processes, and not being able to make plans to solve problems appropriately. Misconception is errors made consistently in different contexts or problems.

Other mistakes made by students when working on mathematics according to [1415] are as follows.

1. Students do not grasp mathematical concepts correctly.

Students have not yet arrived at the process of abstraction; they are still in a concrete world. Students only get to the problems of the instrument, which only knows the examples but cannot describe it. Students have not yet reached the understanding of relations, which can explain the relationship between other concepts derived from previous concepts that have not been understood.

2. Students do not grasp the meaning of symbols.

Students can only describe or pronounce without being able to use it. As a result, all mathematical sentences become meaningless to them, so students manipulate the symbols themselves.

3. Students do not understand the origin of a principle. 
Students know what the formula is and how to use it, but don't know why the formula is used. As a result, students do not know where or in what context the principle is used.

4. Students do not use operations and procedures smoothly.

Non-operation of using previous operations and procedures affects the understanding of subsequent procedures.

5. Incomplete knowledge.

This can hamper students' ability to solve mathematical problems.

Based on the description, in this study, the types of errors in the mathematical work in question consist of misunderstanding the concept, misconceptions, arithmetic errors, procedural errors and errors in understanding symbols.

\subsection{Misconception}

The misconception is one type of error made by students in math work. Conception is a person's understanding or interpretation of a certain concept [4-15]. Another opinion states, conception is a concept that is owned by someone through reasoning, intuition, culture, life experience or something else [16]. Differences in conceptions that occur between individuals occur due to several factors, including knowledge and experience that has been previously owned, the structure of knowledge that has formed in the brain, and differences in perception when receiving information on learning. The more active a person is in learning, the more conception they will make.

The conception that is different from the conception of experts or different from scientific conception and appears consistently in different contexts as a result of errors in the cognitive structure of students is called misconception [4-16]. Misconception is an interpretation of concepts in an inaccurate statement, use of wrong concepts, classification of wrong examples, and hierarchical relationships of concepts that are not true [17]. The characteristics of misconceptions according to [416], namely: misconceptions are resistant or difficult to repair; misconceptions experienced by students if not immediately handled will interfere with the understanding of further concepts. Therefore, in handling misconceptions requires a special strategy.

\subsection{Cognitive conflict strategies}

Cognitive conflict arose from Piaget's research findings in the 1970s [10-18]. The results of this research indicate that cognitive conflict can support cognitive development through the equilibration process. Piaget claims that the first source in the development of knowledge is the emergence of imbalances (imbalances) that encourage a person to try new equilibrium through the process of assimilation and accommodation. Piaget's claim is used as a reference in formulating an understanding of the cognitive conflict. Miscel [19-20] defines that cognitive conflict is a situation where an individual's consciousness experiences an imbalance. This 
imbalance is based on the awareness of information that contradicts the information that has been stored in the cognitive structure. However, cognitive conflict can also occur in the realm of the social environment.

[16] argues that when students are in a conflict situation, students will utilize their cognitive abilities to justify, confirm or verify their opinions. For example, students will use their memory and understanding of a mathematical concept or experience to make the right decision. In these situations, students can get help or clarity from the environment, including from teachers, adults or students who are smarter (scaffolding). In other words, cognitive conflict in someone who responded appropriately or positively can refresh and empower their cognitive abilities.

The interaction between cognitive structures and the environment in giving rise to conflict is illustrated by [16] in the form of Figure 1.

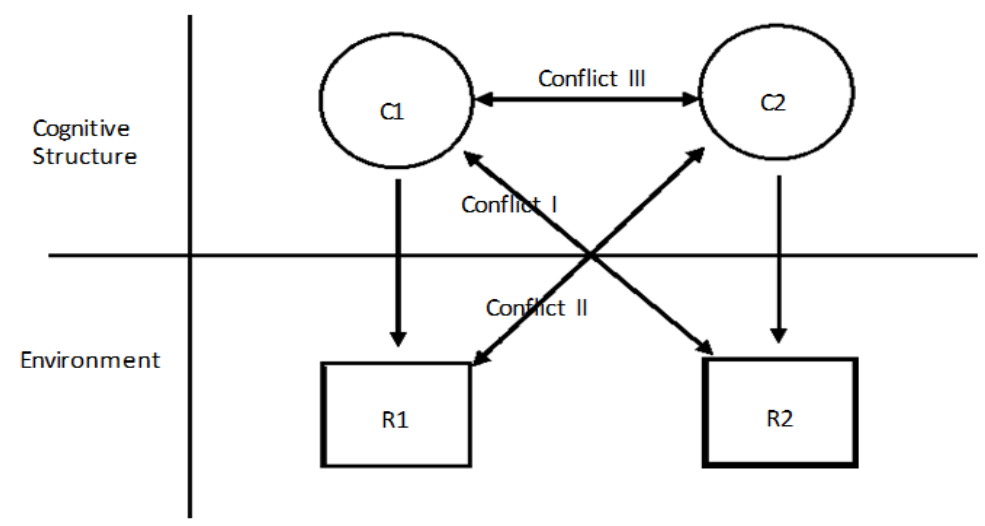

Fig. 1. Cognitive Conflict Strategies

Figure 1 explains the cognitive structure that consists of $\mathrm{C} 1$ and $\mathrm{C} 2$, while $\mathrm{R} 1$ and $\mathrm{R} 2$ illustrate the environmental stimulus. $\mathrm{C} 1$ illustrates the initial concepts that exist in students who are very likely students' misconceptions. $\mathrm{C} 2$ is a concept that will be studied. $\mathrm{R} 1$ represents the environment that can be explained by $\mathrm{C} 1$, and $\mathrm{R} 2$ represents the environment that can be explained by $\mathrm{C} 2$.

Conflict 1 is a type of conflict raised by Piaget, namely between $\mathrm{C} 1$ and $\mathrm{R} 2$ or between students' initial concepts and the environment that can be explained by the concepts to be learned. Conflict 2, namely between what will be learned by students with an environment that can be explained by students' initial concepts. The conflict 3 , namely the conflict between the initial concepts of students with what students will learn.

According to Piaget [10-15-16], a cognitive structure always integrates with its environment through assimilation and accommodation. If assimilation and accommodation occur freely with their environment (conflict-free), then the cognitive structure is in a state of equilibrium with its environment. However, if this does not happen to someone, then the person is said to be in an unbalanced or disequilibrium state. When 
someone is in or experiencing an imbalance, then they will respond to the situation and seek a new balance with the environment. Piaget further said that there are three stages or levels of cognitive conflict processes, namely low level, middle level and high level. At a low level, cognitive balance occurs, so cognitive conflict does not occur despite assimilation and accommodation. At this level, new information is assimilated and accommodated properly by the schemata that already exist in mind. At the intermediate level, there is a cognitive imbalance or conflict occurs. This happens because of the lack of data in mind, so the information obtained does not match the knowledge or cognitive structure (schemata) possessed. This means that the information cannot be assimilated. As a result, the accommodation process does not occur for that information. For this reason, at this level, scaffolding is needed, both by the teacher and by peers who do not experience cognitive conflict. At a high level, there is a re-equilibrium due to the reconciliation of information, resulting in a new balance of what was previously in conflict. At this level, the balance occurs due to interventions or scaffolding done intentionally by the teacher or other sources, so that the process of assimilation and accommodation takes place smoothly. Thus, it can be concluded that cognitive imbalance or cognitive conflict can and needs to be conditioned so that there is a balance at a higher level than the previous balance.

According to [6] the phases of the cognitive conflict strategy consist of introduction, exploration, accommodation, resolution and generalization, which are described in more detail in table 1 .

Table 1. Phases of Cognitive Conflict Strategy

\begin{tabular}{|l|l|}
\hline \multicolumn{1}{|c|}{ Phases } & \multicolumn{1}{c|}{ Activity } \\
\hline Introduction & $\begin{array}{l}\text { Involve students with challenging mathematical problems and identification of } \\
\text { conceptions through their initial responses. }\end{array}$ \\
\hline Exploration & $\begin{array}{l}\text { Experiment with students' ideas to solve problems. Alternative concepts are iden- } \\
\text { tified and compared with asking questions until a cognitive conflict occurs. }\end{array}$ \\
\hline Accommodation & $\begin{array}{l}\text { Cognitive conflict increases with questions and differences in events until stu- } \\
\text { dents acknowledge that their existing ideas are inappropriate. At this point, stu- } \\
\text { dents are observed to change their minds and develop new ideas or conceptions } \\
\text { that explain facts that can be better observed. }\end{array}$ \\
\hline Resolution & Students solve initial challenging problems by using their new ideas. \\
\hline Generalization & Students apply new concepts to solve challenging problems. \\
\hline
\end{tabular}

According to [15-16] misconceptions are resistant, in the sense that they are not easy to repair because someday they can reappear. Therefore, it requires an appropriate strategy specifically designed to reduce student misconceptions. Implementation of Cognitive Conflict Strategies, in reality, requires relatively more time, especially to shake the misconceptions experienced by students. Therefore, we need a facility to be able to overcome this problem. Learning services carried out in this study are learning services through e-service learning. 


\section{$2.4 \quad$ E-Service learning model}

The e-service learning model is based on a notion of connectivity. Connectivism can be used as a theory of learning for the following reasons. First, connectedness is characterized as an increase in how students learn the knowledge and perceptions obtained through the addition of personal networks. Through a network system, students can learn from various viewpoints with a diversity of opinions to make a decision. Second, students can learn from a variety of learning resources to collect information critically. Third, knowledge can be obtained through a technology that is developing quickly. Where is knowledge found to be more important than how is knowledge? [21].

The development of knowledge and the complexity of people's lives in the digital age requires a learning model that is not linear like the learning model previously applied. Technological progress demands a paradigm shift in the delivery of education. With the rise of technology through internet/online connections, social life is a collective network both locally and globally and collaborates on a variety of topics. This paradigm shift, to be used as a consideration in implementing the education system that is not only limited in the classroom and effective time at school [21]. One of the online education systems is service-learning.

Service-learning in the administration of education is defined as academic services that involve the participation of students to get a better understanding of learning materials and can provide a deeper appreciation of the use of learning materials in real life. The implementation of learning is not limited to classrooms, textbooks and memorizing material as in traditional learning. Service-learning places more emphasis on collaborative work than on individual work. Besides this, it trains a sense of responsibility and a sense of togetherness among students [22-23]. According to [23] learning service is a learning service that allows students to learn by doing, connecting theory with practice. This is a method of learning with active participation through organized experience according to community needs. Further said, service-learning can be divided into three, namely: Extreme e-service learning is a component of learning and services are done online; Traditional service-learning is face-to-face learning with service in place and class ;

And e-service learning is a combination of face-to-face service components followed by online services or vice versa.

Learning services conducted online or e-service learning by social constructivism theory. Its implementation emphasizes the occurrence of social interaction in the educational environment and training people to spread knowledge to others. This ability will lead to the development of intellectual abilities, social skills and scientific skills [24-25]. The e-service learning model is a learning service model that combines online and face-to-face learning. Students are trained to be involved in global relationships and real environments. The stages of learning using e-service learning are problem investigation, design, action, reflection and demonstration [22]. 


\section{Research Methods}

This research was conducted on grade VII junior high school (SMP) students in Buleleng regency, Bali. Sampling was done by cluster random sampling technique by considering three areas, namely SMP located in urban, suburban and rural areas. The three selected junior high schools are SMP 2 Singaraja for urban areas with 38 people, SMP 4 Singaraja for suburban areas with 36 people, and SMP 2 Banjar for rural areas, as many as 35 people. Thus, the total sample involved in this study was 109 people.

The procedure of this research begins by developing e-service learning media using the ADDIE model, with steps consisting of analysis, design, development, implementation and evaluation [26]. The results of the development of e-service learning media in this study, including the menu structure (sitemap) on e-service learning consists of five main menus namely Home, Guidelines (Petunjuk), Curriculum (Kurikulum), Learning Activities (Aktivitas Pembelajaran), Exercises (Latihan), Forums (Forum), and Developers (Pengembang) as in Figure 2.

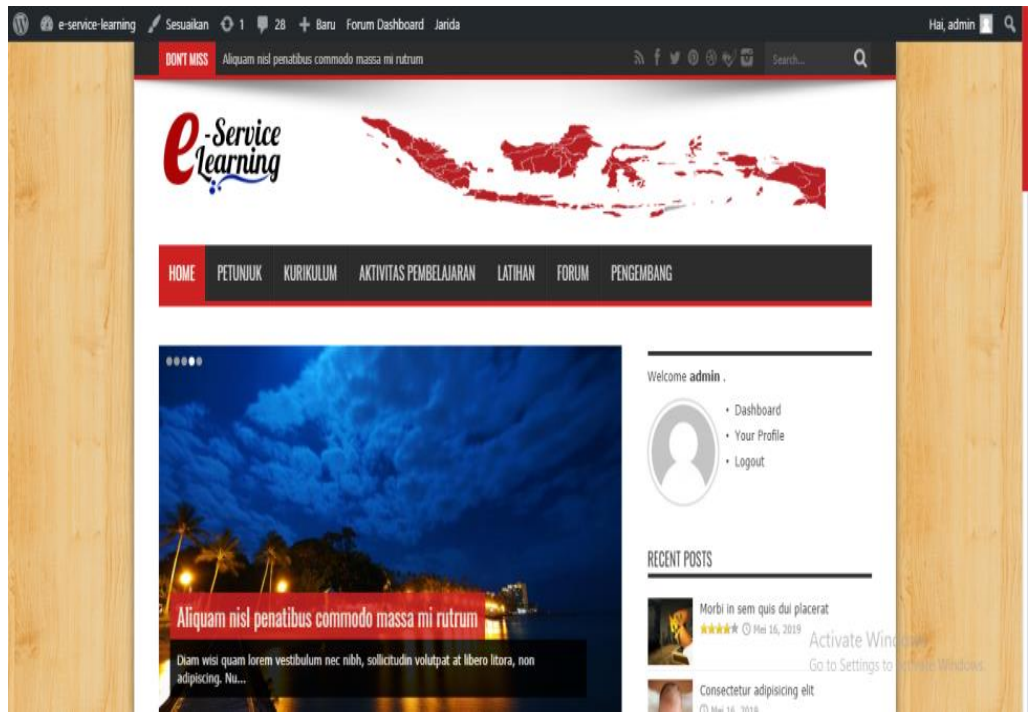

Fig. 2. Media e-Service Learning

The structure of the material and learning activities are adjusted to the stages of learning with a cognitive conflict strategy using e-Service Learning as shown in table 2. 
Table 2. Structure of learning materials based on e-Service Learning

\begin{tabular}{|c|l|l|}
\hline No & \multicolumn{1}{|c|}{ Learning Activities } & \multicolumn{1}{c|}{ Media Content } \\
\hline 1 & Problem Investigation & $\begin{array}{l}\text { Given a narrative text, learning videos in the form of problems } \\
\text { that occur by the environment of students. }\end{array}$ \\
\hline 2 & Design & $\begin{array}{l}\text { Students do the design by holding discussions with their com- } \\
\text { munities on the forum menu. }\end{array}$ \\
\hline 3 & Action & $\begin{array}{l}\text { Learners discuss the design of action by uploading work on the } \\
\text { post writing feature. }\end{array}$ \\
\hline 4 & Reflection & $\begin{array}{l}\text { Students do reflection by commenting on the work of other stu- } \\
\text { dents who have been posted via face-to-face or online. }\end{array}$ \\
\hline 5 & Demonstration & $\begin{array}{l}\text { Students demonstrate in a class by reporting on the results ob- } \\
\text { tained during learning. }\end{array}$ \\
\hline
\end{tabular}

This research data was collected using tests, observation sheets and interview guidelines. The test used is a description test consisting of five items with material number operations. Before being used, the test was validated by three experts and tested empirically. The results of the validation by the experts showed that the test instrument was valid, and the empirical test showed that the instrument had met the valid and reliable criteria, with a reliability coefficient of 0.87 .

Observation sheets include evaluating the implementation of learning in the classroom using Cognitive Conflict Strategies. Components observed included: students' enthusiasm in participating in learning; ability to cooperate; ability to express opinions; and respond to friends' opinions. Observation sheets are arranged using a Likert scale with five gradation choices, namely: (1) Very poor, (2) Poor, (3) Sufficient, (4) Good, (5) Very good.

The interview guide used is an open interview guide. Interviews were conducted with students, related to the types of errors in working on mathematical problems carried out. This data is used to supplement and strengthen the data of the mathematical problem-solving ability test results.

Data analysis was performed descriptively and qualitatively. Descriptive analysis is performed related to the percentage of types of errors made by students in working on mathematical problems. Qualitative analysis is carried out in stages: data collection, data reduction, verification and making conclusions. A test of the effectiveness of the implementation of learning models on students' mathematical problem-solving abilities was analyzed using t-test with a significance level $\alpha=0.05$. A T-test is done by comparing the average test results of students' mathematical problem-solving abilities, before and after the cognitive conflict strategy is implemented assisted by e-Service Learning.

\section{$4 \quad$ Results and Discussion}

\subsection{Research results}

The types of math work errors identified in this study are (1) substantial errors, which include: misconceptions of concepts and misconceptions; and (2) technical errors, 
including errors in performing arithmetic operations; imperfect completion procedures, and not understanding symbols. Thus there are five types of math errors made by students, namely, misunderstanding the concept (type 1), misconceptions (type 2), arithmetic errors (type 3), procedural errors (type 4), and errors in understanding symbols (type 5). The types of student mistakes are shown in Table 3.

Table 3. Types of Mistakes Made by Students

\begin{tabular}{|c|c|c|c|c|c|}
\hline \multirow{2}{*}{$\begin{array}{c}\text { Question } \\
\text { Number }\end{array}$} & \multicolumn{5}{|c|}{ Many Students Make Mistakes } \\
\cline { 2 - 6 } & Type 1 & Type 2 & Type 3 & Type 4 & Type 5 \\
\hline 1 & 20 & 7 & 15 & 16 & 13 \\
\hline 2 & 24 & 8 & 14 & 12 & 14 \\
\hline 3 & 22 & 8 & 15 & 16 & 14 \\
\hline 4 & 25 & 7 & 12 & 17 & 15 \\
\hline 5 & 30 & 9 & 18 & 18 & 18 \\
\hline Total & 121 & 39 & 74 & 79 & 74 \\
\hline Average (\%) & 22.2 & 7.2 & 13.6 & 14.5 & 13.6 \\
\hline
\end{tabular}

Based on Table 3, the average number of students who experience type 1, type 2, type 3 , type 4 and type 5 errors are respectively $22.2 \%, 7.2 \%, 13.6 \%, 14.5 \%$, and $13.6 \%$. This shows that most mistakes made by students are type 1 (misunderstanding the concept), while the least is type 2 errors (misconceptions). The number of students experiencing type 3 , type 4 and type 5 errors is relatively the same, namely 13.6\%; $14.5 \%$; and $13.6 \%$.

The effectiveness test results of implementing Cognitive Conflict Strategy assisted by e-Service Learning are respectively shown in Table 4 and Table 5.

Table 4. Paired Samples Statistics

\begin{tabular}{|l|l|c|c|c|c|}
\hline & & Mean & N & Std. Deviation & Std. Error Mean \\
\hline \multirow{2}{*}{ Pair 1 } & First Test & 74.24 & 109 & 3.605 & .345 \\
\cline { 2 - 6 } & Second Test & 77.05 & 109 & 3.743 & .358 \\
\hline
\end{tabular}

Table 5. Paired Sample Test

\begin{tabular}{|c|c|c|c|c|c|c|c|c|c|}
\hline & & \multicolumn{5}{|c|}{ Paired Differences } & \multirow[b]{3}{*}{$t$} & \multirow[b]{3}{*}{$d f$} & \multirow{3}{*}{$\begin{array}{l}\text { Sig. }(2- \\
\text { tailed })\end{array}$} \\
\hline & & \multirow[b]{2}{*}{ Mean } & \multirow[b]{2}{*}{ Std. Deviation } & \multirow{2}{*}{$\begin{array}{c}\text { Std. Error } \\
\text { Mean }\end{array}$} & \multicolumn{2}{|c|}{$\begin{array}{l}95 \% \text { Confidence } \\
\text { Interval of the Dif- } \\
\text { ference }\end{array}$} & & & \\
\hline & & & & & Lower & Upper & & & \\
\hline Pair 1 & $\begin{array}{l}\text { First Test - } \\
\text { Second } \\
\text { Test }\end{array}$ & -2.807 & 3.056 & .293 & -3.388 & -2.227 & -9.589 & 108 & .000 \\
\hline
\end{tabular}

The average problem-solving ability before and after the implementation of Cognitive Conflict Strategies assisted by e-service learning is 74.24 and 77.05. Because the value of $\operatorname{sig}=0.00(<\alpha=0.05)$, the mean difference before and after treatment is 
significant. In other words, students' problem-solving abilities after applying Cognitive Conflict Strategies assisted by e-Service Learning are better than before.

\subsection{Discussion}

By the results of the study above, there are differences in the number of students who experience type 1 and type 2 errors, because among students who do not understand the concept there are errors that are consistent and some are not. Students do not understand the concept because they do not understand the concept of place values and not because of consistent mistakes. The following is an example of the work of students who experienced a type 1 error but did not experience a type 2 error (a comma in Indonesian is the same as a dot in English).

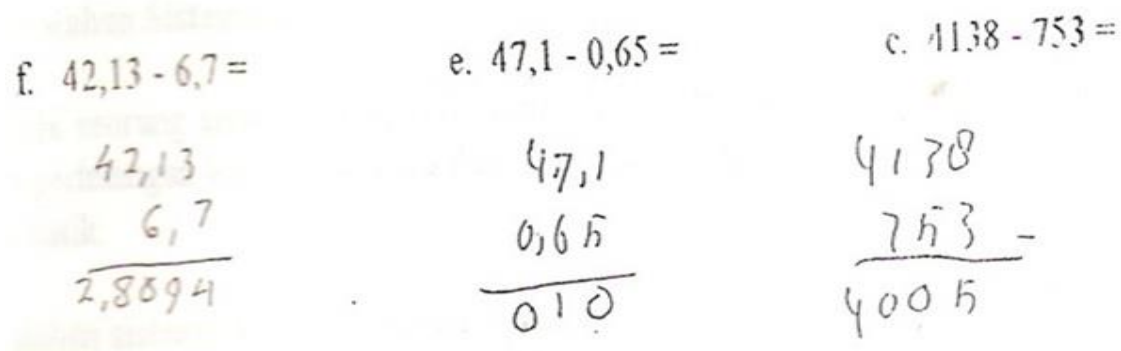

Fig. 3. Example of Type 1 Error, but not Experiencing Type 2 Error

The application of cognitive conflict strategies assisted by e-service learning can reduce misconceptions and improve students' abilities in solving mathematical problems.

Questions given to students include the following.

1. Ibu Made has 4,138 sweets to be distributed to 753 children. How many sweets can Ibu Made give to each child? Give a reason!

2. Today Uncle has 32.49 meters of rope that will be used to complete his garden fence ties. Then the sister asked for 8.62 meters to tie the toy she made. Every 10 meters of fence Uncle made requires a rope as long as 2 meters. How long is the fence that Uncle can finish today?

Students do it by doing repetitive reductions. Students who experience misconceptions work on this problem as in Figure 4. 


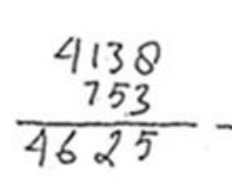

(1)

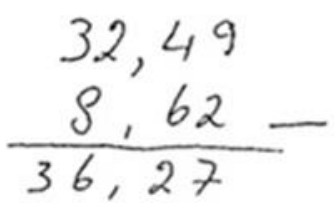

(2)

Fig. 4. Examples of Student Work in Working on a Problem No. 1 and No. 2

It seems that the misconception experienced by students is making consistent mistakes when working on a number reduction operation, which is subtracting a larger number by saying a smaller one, without considering the position of the reduced number and subtraction.

Handling this problem by applying a cognitive conflict strategy (as in figure 01) is done in the following way.

1. C1: Student misconceptions

$-47.65-0.74=47.11$

$-35.28-6.73=31.55$

2. Presenting R1:

$47.85-2.64=45.21$ (ask students to check whether $2.64+45.21=47.85$ ? the answer is correct) (cognitive conflict does not occur because according to the correct concept).

3. Presenting R2:

$45.27-6.75=41.52$ (ask students to check whether $6.75+41.52=45.27 ?$ the results do not match; i.e., $48.27 \neq 45.27$ (R2 is incompatible with $\mathrm{C} 1$, a cognitive conflict situation occurs-1)

4. C2: Correct concept

The decimal number reduction operation is the same as the integer subtraction operation; i.e., the numbers to be subtracted are numbers that have corresponding place values. If the number reduced is smaller than the subtraction number, then the borrowing technique is performed.

Example C1:

1) $47.65-0.74=(4$ tens 7 ones and 6 tenths 5 hundredths minus 0 ones and 7 tenths 4 hundredths).

2) $35.28-6.73=(3$ tens 5 ones and 2 tenths 8 hundredths minus 6 ones and 7 tenths 3 hundredths)

done as follows. 


\begin{tabular}{rr}
47.65 & 2) 35.28 \\
0.74 & 6.73 \\
\hline 46.91 & $\quad$
\end{tabular}

5. The concept of $\mathrm{C} 2$ is incompatible with the concept understood to do R1 (cognitive conflict-2 occurs).

6. The answers obtained when working $\mathrm{R} 2$ are different from the answers in $\mathrm{C} 1$ (conflict-3).

At the sixth stage, students begin to falter with the concepts understood so far. At that time, the teacher directs students (who experience misconceptions) to be able to improve their conception following the correct concept or by scientific concepts. For students who do not experience misconceptions, at this stage, their concept understanding will be strengthened.

Cognitive Conflict Strategies that have been applied in this study have been able to reduce students' misconceptions by $85 \%$ of the total students who experienced them. As much as $15 \%$ cannot be overcome because when they solve the problems given in different situations, they repeat the mistakes made at the beginning (according to their initial knowledge). This is consistent with the opinion [4-16], which says that the misconceptions experienced by students are resistant or difficult to change. Therefore, the handling of errors in the type of misconception requires a special way so that the misconceptions experienced by students can be reduced. This was also conveyed by [4] in his research; of several students who experienced misconceptions, the conception did not change from the initial conception.

On the other hand, for students who do not experience misconceptions, the application of Cognitive Conflict Strategies in learning reinforces students' understanding of concepts. This happens because when students are given examples that are not by scientific concepts (counterexamples), understanding students' concepts will not be shaken. In this case, Cognitive Conflict Strategies are also effective for testing and strengthening students' understanding of concepts. The same research results were also found by [4-10]. Similarly, the results of the study [9] found that through the application of Cognitive Conflict Strategies, students' understanding of concepts would be stronger and the concepts obtained would stay longer in students' minds. This means that misconceptions can be corrected if appropriate learning methods are applied and with relatively longer time.

The application of Cognitive Conflict Strategies in this study was carried out by assisted e-service learning. The implementation is done by providing material services online, followed by face-to-face services in the classroom. Online learning activities are carried out simultaneously for all three schools. Thus, students in learning are not only limited in their classrooms, but they can study anywhere and with anyone as long as there is internet access. Through online activities, students can practice social skills and discuss mathematical problems provided in the form of exercises done online. Through this activity, students have more time to discuss the subject matter with their 
peers and with their supervisor. In this way, too, technological developments can be utilized for positive activities [21].

\section{Conclusion}

Types of mistakes made by students in working with mathematics can be classified into two, namely substantial errors and technical errors. Substantial errors include errors in understanding concepts and misconceptions, while technical errors consist of errors in arithmetic operations, procedural errors, and errors in understanding symbols. Misunderstanding the concept is not being able to plan and solve problems properly. Misconceptions are errors that appear consistently in different contexts as a result of errors in the cognitive structure of students. The number of students who experience misunderstanding of concepts, misconceptions, miscalculating operations, procedural errors, and misunderstanding symbols are respectively $22.2 \%, 7.2 \%, 13.6 \%, 14.5 \%$, and 13 . $6 \%$. The number of students experiencing misconceptions is the least compared to students experiencing other types of errors. Besides, it was found that the application of Cognitive Conflict Strategies assisted by e-Service Learning could reduce students' misconceptions by $85 \%$ of the total students who experienced them and were effective in improving students' mathematical problem-solving abilities.

\section{Acknowledgement}

The author would like to thank the Directorate of Research and Community Service, Ministry of Research and Technology of Higher Education of the Republic of Indonesia for its financial support in conducting this research with research contracts No.: 147/UN48.15/LT/2018 and Head of the Youth and Sports Education Office Buleleng Regency for its cooperation in conducting this research.

\section{$7 \quad$ References}

[1] Ni Nyoman Parwati, I Gusti Putu Sudiarta, I Made Mariawan, I Wayan Widiana. (2018). Local Wisdom-Oriented Problem-Solving Learning Model to Im-prove Mathematical Problem-Solving Ability. Journal of Technology and Science Education (JOTSE), 8(4): xx-yy Online ISSN: 2013-6374 - Print ISSN: 2014-5349. https://doi.org/10.3926/jotse. $\underline{401}$

[2] Sulaka, S. (2010). Effect of problem-solving strategies on problem-solving achievement in primary school mathematics. Procedia Social and Behavioral Sciences, 9 (2010) 468-472. (Available online at: www.sciencedirect.com). https://doi.org/10.1016/j.sbspro.2010.12. 182

[3] Tambychika, T. \& Meerahb, T. S. M. (2010). Students' Difficulties in Mathematics Problem-Solving: What do they Say? International Conference on Mathematics Education Research 2010 (ICMER 2010). Procedia Social and Behavioral Sciences, 8 (2010) 142-151. 
(Available online at: www.sciencedirect.com). https://doi.org/10.1016/j.sbspro.2010.12. $\underline{020}$

[4] Said Fachry Assaraf. (2013). Cognitive Conflict Supported by Context by Overcome Misconception in Mathematics Classroom. Introduction to Science Education and Communication Theories. https://www.researchgate.net/publication/236271839.21 April.

[5] Parakitipong, Natcha and Satoshi Nakamura. (2006). Analysis of Mathematics Performance of Grade Five Students in Thailand Using Newman Procedure. Journal of International Cooperation in Education, 9(1),.111 - 122.

[6] M. Suárez-Pellicioni, M. I. Núñez-Peña, and À. Colomé. (2016). "Math anxiety: A review of its cognitive consequences, psychophysiological correlates, and brain bases," Cogn. Affect. Behav. Neurosci., vol. 16, no. 1, pp. 3-22. https://doi.org/10.3758/s13415-015-0370-7

[7] National Council of Teachers of Mathematics. (2000). "Principles and Standards for School Mathematics," Sch. Sci. Math., vol. 47, no. 8, pp. 868-279.

[8] C. Nagle and D. Moore-Russo. (2014). "Slope Across the Curriculum: Principles and Standards for School Mathematics and Common Core State Standards," Math. Educ., vol. 23, no. 2, pp. 40-59.

[9] Irawati et al. (2018). Cognitive conflict strategy to minimize students' mis-conception on the topic of the addition of algebraic expression. Journal of Physics: Conference Series 1088 012084. https://doi.org/10.1088/1742-6596/1088/1/012084

[10] Andi Fajeriani Wyrasti, Cholis Sa'dijah, Lathiful Anwar. (2016). The Assessment of Students' Cognitive Conflict by Using Student's Cognitive Map in Solving Mathematics Problem. International Conference on Education 2016. Universitas Negeri Malang.

[11] Hattie, J. (2015). The Applicability of Visible Learning to Higher Education. Scholarship of Teaching and Learning in Psychology; American Psychological As-sociation, 1(1), 79-91. Downloaded from result.uit.no/basiskompetanse/wp-ontent/uploads/sites/29/07/Hattie. pdf. https://doi.org/10.1037/st10000021

[12] Farhan, Y. A. (2019). The Role of Cloud Computing for the Enhancement of Teaching and Learning in Saudi Arabian Universities by the Social Constructivism Theory: A Specialist's Point of View. International Journal of Emerging Technologies in Learning (iJET)eISSN:1863-0383-Vol.14, No.13. https://doi.org/10.3991/ijet.v14i13.9557.

[13] M. Nuroniah, R. Rochmad, and K. Wijayanti. (2013). "Analisis Kesalahan dalam Menyelesaikan Soal Pemecahan Masalah dengan Taksonomi Solo," Unnes J. Math. Educ., vol. 2, no. 2. http://repository.uksw.edu/bitstream/123456789/1867/3/T1_202008034. https://doi.org/10.24235/eduma.v7i1.2711

[14] Hjh Roselizawati Hj Sarwadi, Masitah Shahrill. (2014). Understanding Stu-dents' Mathematical Errors and Misconceptions: The Case of Year 11 Repeating Students. Mathematics Education Trends and Research (2014) 1-10. Available online at www.ispacs.com/metr. https://doi.org/10.5899/2014/metr-00051

[15] Rana Ghulam Mohyuddin \& Usman Khalil. (2016). Misconceptions of Stu-dents in Learning Mathematics at Primary Level. Bulletin of Education and Re-search, June, Vol. 38, No. 1 pp. $133-162$

[16] Lee, G. \& Kwon, J. (2001). What Do We Know about Students' Cognitive Conflict in Science Classroom: A Theoretical Model of Cognitive Conflict Process. Proceedings of the Annual Meeting of the Association for The Education of Teachers in Science. Costa Mesa, CA: ERIC.

[17] Hunsik, K., Lawrence, C. S., Sukjin, K., \& Taehee, N. (2010). Cognitive conflict and situational interest as factors influencing conceptual change. International Journal of Environmental \& Science Education Vol. 5, No. 4, October, 383-405. ISSN 1306-3065. http://www.ijese.com/ 
[18] Dewi Herawati dan Wahyu Widada. (2017). The Influence of Contextual Learning Models and the Cognitive Conflict to Understand Mathematical Concepts and Problems Solving Abilities. First International Conference on Science, Mathematics, and Education, (ICoMSE). https://doi.org/10.2991/icomse-17.2018.17

[19] Lee, G., Kwon, J., Park, S.S., Kim, J.W., Kwon, H.G., Park, H.K. (2003). De-velopment of an Instrument for Measuring Cognitive Conflict in Secondary-Level Science Classes. Journal of Research in Science Teaching, 40(6), 585-603. https://doi.org/10.1002/tea.10099

[20] Kennedy, T. (2015). Addressing Alternative Conceptions in Mathematics Using Discrepant Events. In Mathematics: Learn, Lead, Link (Proceedings of the 25th biennial conference of the Australian Association of Mathematics Teachers, pp. 71-78). Adelaide: AAMT.

[21] Siemens, G. (2005). Connectivism: A learning theory for the digital age. International Journal of Instructional Technology and Distance Learning, 2(1). Retrieved from: http://www.itdl.org/

[22] Harris, U. S. (2017). Virtual Partnerships: Engaging Students in E-service Learning Using Computer-mediated Communication. Asia Pacific Media Educator 27(1) 103-117. http://ame.sagepub.com. https://doi.org/10.1177/1326365x17701792

[23] Waldner, L. S., McGorry, S. Y., \& Widener, M. C. (2012). E-service-learning: The evolution of service-learning to engage a growing online student population. Journal of Higher Education Outreach and Engagement, 16(2), 123-150.

[24] Farhan Yetaim Alenezi. (2019). The Role of Cloud Computing for the Enhancement of Teaching and Learning in Saudi Arabian Universities following the Social Constructivism Theory: A Specialist's Point of View. International Journal of Emerging Technologies in Learning (iJET)-eISSN: 1863-0383- Vol. 14, No. 13, 2019. https://doi.org/10.3991/ijet. v14i13.9557

[25] Pratya Nuankaew, Wongpanya Nuankaew, Kanakarn Phanniphong, Sasithon Imwut, Sittichai Bussaman. (2019). Students Model in Different Learning Styles of Academic Achievement at the University of Phayao, Thailand. Interna-tional Journal of Emerging Technologies in Learning (iJET)-eISSN: 1863-0383- Vol. 14, No. 12, 2019. https://doi. org/10.3991/ijet.v14i12.10352

[26] Kurt, S. (2017). "ADDIE Model: Instructional Design," in Educational Tech-nology, August 29. Retrieved from: https://educationaltechnology.net/the-addie-model-instructional-design/.

\section{Authors}

Ni Nyoman Parwati is a associate professor in the Department of Mathematics Education and Masters in Learning Technology, Universitas Pendidikan Ganesha, Singaraja, Bali, Indonesia. Megister in the field of Mathematics Education was obtained from IKIP Negeri Malang, Indonesia. A Doctor in the field of Learning Technology was obtained from Malang State University, Indonesia. Her research area is mathematics learning technology. The courses she has taught include Teaching and Learning, Teaching and Learning Strategies, Number Theory, and Trigonometry.

I Gusti Putu Suharta is a Professor in Mathematics Education and a lecturer in undergraduate and postgraduate, Department of Mathematics Education, Universitas Pendidikan Ganesha, Singaraja, Bali, Indonesia. The Magister in Mathematics was obtained from Gajah Mada University, Indonesia. A doctorate in Mathematics Education was obtained from Surabaya State University, Indonesia. His research area is 
Paper-Effectiveness of the Implementation of Cognitive Conflict Strategy Assisted by e-Service...

mathematics education. The courses that he has taught include Study of Mathematics Education Curriculum, Research Methodology, and Statistics. Email address: putu.suharta@undiksha.ac.id.

Article submitted 2019-10-01. Resubmitted 2020-01-27. Final acceptance 2020-01-30. Final version published as submitted by the authors. 